\title{
Title: Polyamines-A Positive Modulator against Biotic and Abiotic Stresses on Plants: Review of current knowledge.
}

\author{
AUTHORS: Md. Al-Amin Milon ${ }^{1}$, Mst. Lutfa Khatun ${ }^{1}$, Md. Azizul Islam* \\ AFFILIATIONS: \\ 1 Department of Biotechnology and Genetic Engineering, Faculty of Biological Sciences, \\ Islamic University, Kushtia-7003, Bangladesh. \\ *Address correspondence to: azizbge.iu@gmail.com
}

\begin{abstract}
The biotic and abiotic stresses are the main causes to the loss of agricultural crops productivity, their normal growth and development in the environment. It has been calculated that two-thirds of the major crops are frequently lost due to the adverse environmental conditions. The productivity of crops under unfavorable environmental stresses is apparently the main challenge to the breeders and farmers where polyamines (PAs) play a diverse roles to environmental stimuli. PAs (putrescine, spermidine and spermine) are low molecular weight positively charge compounds have active potential power to negative charge molecules (DNA, RNA and proteins) in widely distributed all living organisms. Evidences showed that PAs contribute a lot of different physiological and biological functions, such as cell growth and development, controlling the cell cycle, involve in gene expression, cell signaling, replication, transcription, translation and membrane stabilization. Naturally occurring polyamines activity acuminated to their involvement with different biotic and abiotic stresses and contribute the survival of plant in environment. Here, we have described the potential mechanisms, synthesis and various role of PAs during stresses tolerant and diseases resistance.
\end{abstract}

Key words: Plants, polyamines, abiotic stresses, biotic stresses, transgenic plants, Plantpathogen interaction, Plants-fungal interaction. 


\section{INTRODUCTION:}

Polyamines (PA) are smaller molecular weight nitrogenous aliphatic compounds with effective bioactivity, actually contains 2 or more amino groups (1). These remain commonly spread in eukaryotic and prokaryotic cells (2). Polyamine (tetraamine Spermine) was first reported in human spermatozoa for around 300 years ago (3). In plants, diamine Putrescine (Put), triamine Spermidine (Spd), and tetraamine spermine (Spm) Clearly greater part widespread PAs. In regards, the structural isomer Spm thermo-spermine (T-Spm) was actually recognized mostly as a ubiquitous PA in plants (4). In generally higher trees and microorganisms, the first phase in PA biosynthesis is either ornithine or arginine, while ornithine decarboxylase and Arginine decarboxylase enzymes are stimulated in the process. On the opposite, just one path (ODC reaction) significantly contributed to the formation of Put in mammals and fungi (5).

Times over the past ten years, however, In-plant molecular research with PA significant genes from a variety of plant species expressing PA bio-catalytic enzymes have been identified (6). They may also adhere unspecifiable to distinct proteins, stabilize their structure and proceed with alterations in their functions, including chromatin, adding to a modification of genomic sites' accessible supply of polymerases of Deoxyribonucleic acid (DNA) or Ribonucleic acid(RNA) resulting to change to DNA synthesis and RNA (7). The effects on the growth and development of plants; polyamines have had a tremendous impact (8). The same as hormones PAs participate in functions including replication, transcript, translations, and membrane stabilization, Controlled of enzyme activity (9). Significant attention becomes paid to stress-induced PA accumulation and therefore its protective role towards biotic stress and abiotic stresses. Throughout this study, we attempted to organize the knowledge obtained science the last few decades on PA metabolism's function throughout plants under different 
stress of environment respectively abiotic stress and biotic stress including address the impact on plant and the development of polyamines.

It is well documented that PAs participation in the defense mechanism reaction in plants against biotic and abiotic stresses $(9,10)$. PAs metabolism genes for enzymes have been cloned from several species and their expression level under biotic and abiotic stress conditions has been analyzed. Islam et al (2019) found that PAs biosynthesis-related genes $A D C 1, O D C$, and Arginase were significantly down regulated and SAMDC was up regulated by salt treatment and accumulation of Put and Spd reduced salt tolerance in rice by facilitating ROS production. PAs biosynthesis genes in rice plants can enhance stress tolerance by preventing the accumulation of ROS (11). It has been reported that abiotic stresses influences endogenous PAs metabolism in plants, and exogenous PAs level alleviate the effects of abiotic stresses on various plants by reducing damage to cell membrane and lipid oxidation $(12,13)$.

Polyamines in plants are also contributing for agro-economic importance, including phytonutrient content, fruit quality, and vine life $(1,14)$ and have defense response against the pathogen attack and reduce diseases (15). It's metabolism in plant cells create a suitable environment for the interacting the pathogens, such as fungal (16) viral pathogens (17) and mycorrhizae (1). Therefore, spermine ( $\mathrm{Spm}$ ) not only plays a role as a mediator in defense signaling against pathogen $(4,13)$ but is also important for resistance to virus infection $(18)$. In this review, we summarize plant polyamines metabolism and their functions, with specific feature on biotic and abiotic responses.

\section{BIOSYNTHESIS OF POLYAMINE:}

Polyamines biosynthesis has three distinct routes in plants and these routes have already been extensively studied (Figure 1). In the first path, Arginine-decarboxylase (ADC) eliminates the number of eight carbon-atoms from arginine (Arg), and Agmatine (agm) and $\mathrm{CO} 2$ are formed. The number atom from Agm is dropped and N-carbamoyl Put (NCPA) and NH3 are formed. Then N-carbamoyl Putrescine amidohydrolase (NCPAH) causes hydrolyzing of NCPA and Put, CO2, and NH3 are formed by elimination of carbamoyl group. In plants, it is 
the principal route of put synthesis (19).

In the second path, Arginase induced Arg to form ornithine (Orn). Then the carboxyl group of the number one carbon atom of Orn is released by ornithine decarboxylase (ODC) and result Put and $\mathrm{CO} 2$ are formed (20). Arabidopsis thaliana and other members of Brassicaceae lost the ODC gene, which reveals that the regulation of ornithine pathway is not required (21). In the third path, Arg is transformed into Citrulline (cit) first and then decarboxylated with Citrulline decarboxylase (CDC) as a result put is formed (2).

The cit pathway has been found only in sesame; therefore the initial two pathways in plants are most frequent. Difluoro methyl arginine (DFMA) and Difluoro methyl ornithine (DFMO) are persistent efficient inhibitors that can inhibit the function of Arginine-decarboxylase (ADC) and ornithine decarboxylase (ODC ) (22). Put and aminopropyl residues, significantly provided with methionine and they are the source of Spd and Spm $(23,24)$.

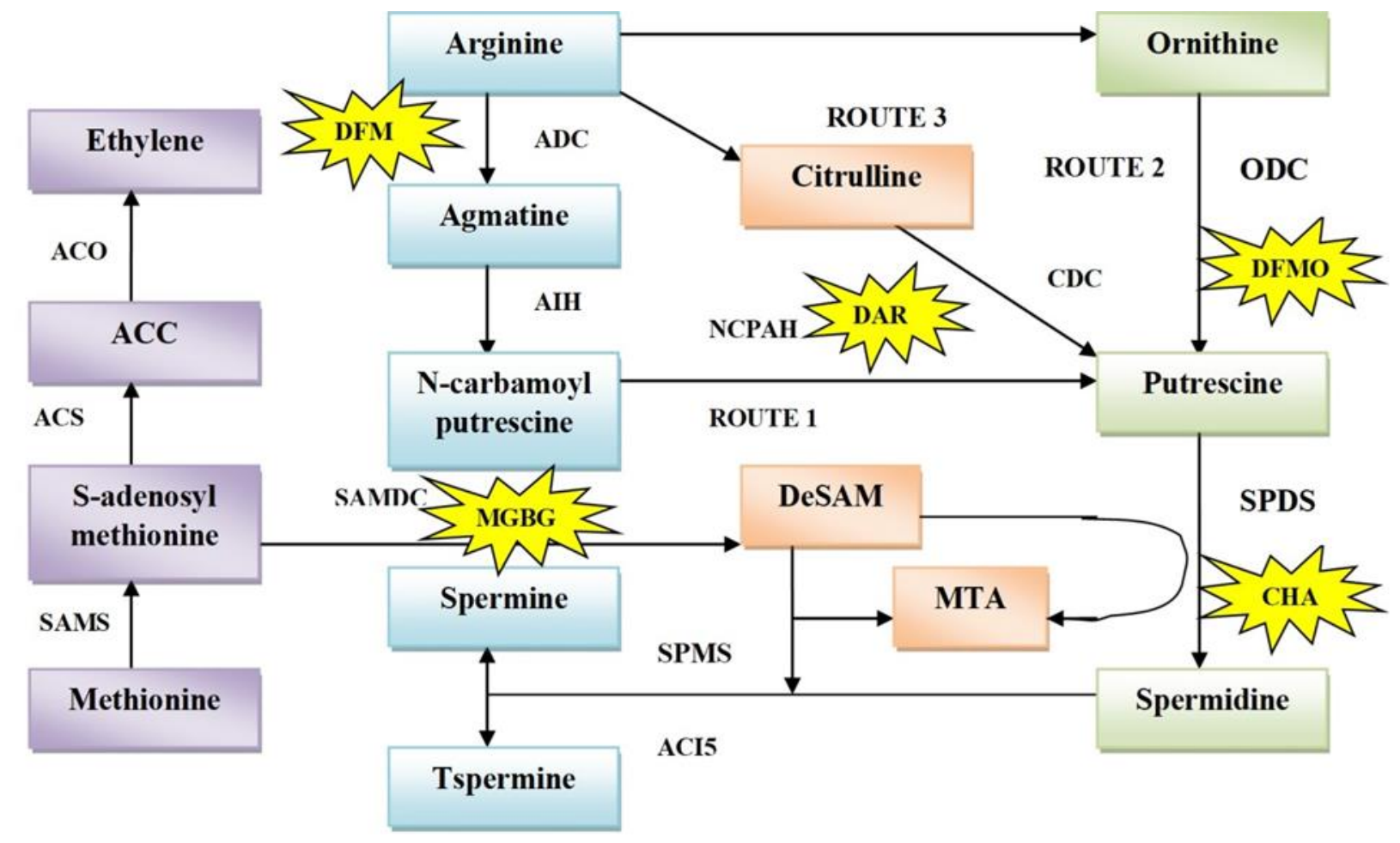

Figure 1: Biosynthesis of polyamines (24) 


\section{CATABOLISM OF POLYAMINE:}

The polyamines concentration in the cells is also controlled by catabolic pathways $(6,17)$. In the process of the PA catabolism of plants (Figure 2), two groups of enzymes are involved. These are copper-containing amine oxidases (AOs) and flavin-containing Polyamine oxidases (PAOs). AOs catalyze their respective amino aldehydes by oxidation of Put and Spd with the simultaneous manufacture of the Ammonia and $\mathrm{H}_{2} \mathrm{O}_{2}$ (25). Nevertheless, PA-Oxidation information still it appears that it is ambiguous as only four have been biochemically characterized because of the tent AO genes notice in the Arabidopsis (26). According to the reaction modes, there are two separate types of PAOs: terminal catabolism and backconversion. PAOs in their secondary amino groups oxidize substrates, Spermidine and Spermine, therefore, yields pyrrolineand 1, 5-diabicylcononane, respectively $(27,28)$. Five PAO genes are retained in Arabidopsis. PAO1 and PAO4 were able to convert Spm to Spd and PAO2 and PAO3 were capable of catalyzing Spd from Spm and afterward produce Put (29). In the signal transmission cycle of plants, the $\mathrm{H}_{2} \mathrm{O}_{2}$, produced through PA oxidation, acts during biotic and abiotic stress responses (30,31).

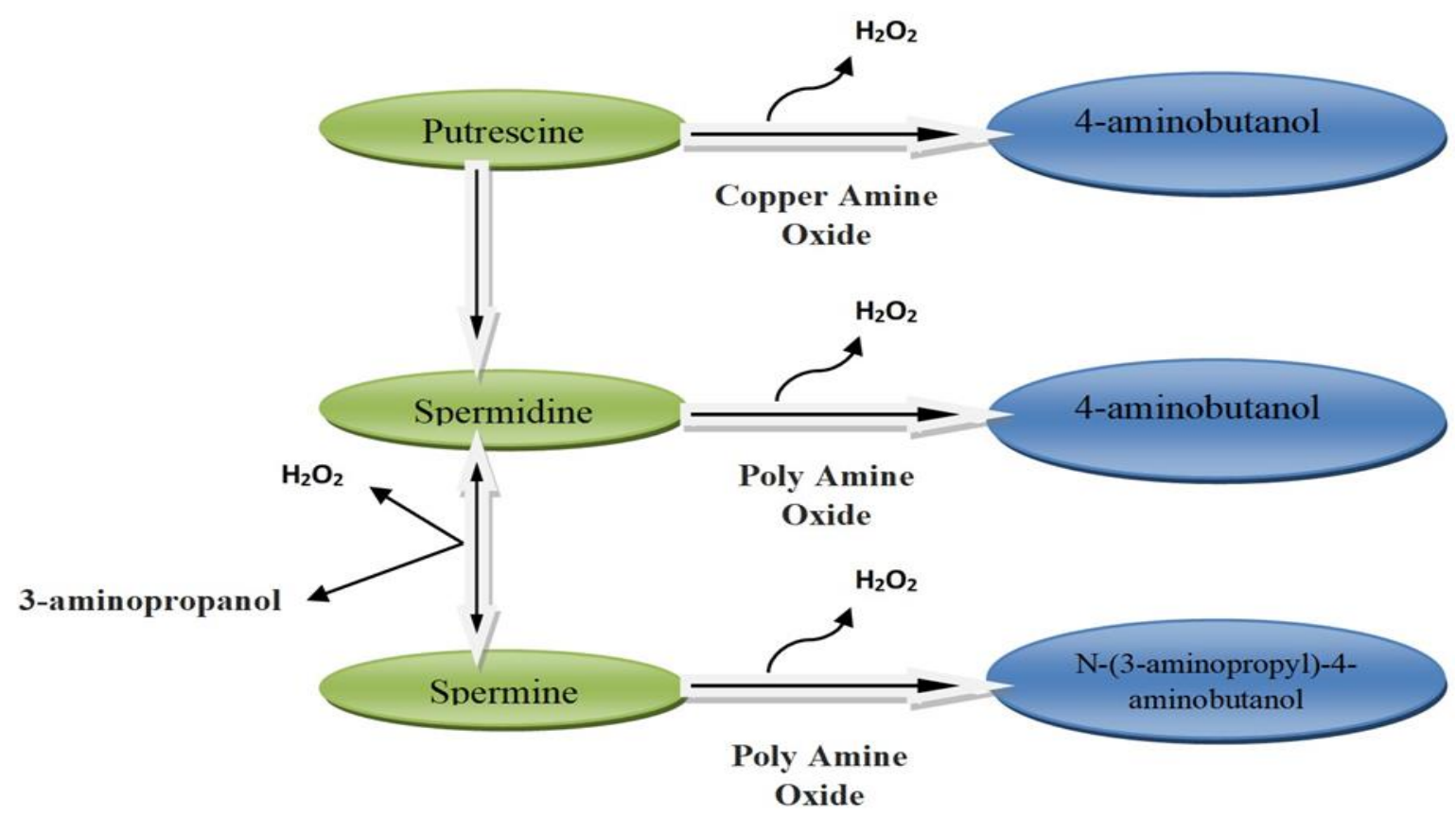

Figure 2: Polyamines degradation in plants (31) 


\section{PLANT DEVELOPMENT AND POLYAMINE:}

The significant effects of polyamines are being noted in plant growth and development (8). In terms of the total and individual quantities of polyamines, both plants or organs and the stage of growth are substantially different (32).

\subsection{Polyamines and Flowering:}

Plant species enter a stage of reproductive phase during a vegan development period; so that the leaf buds tissue transfers its own physiological state to a flowering tissue and ultimately becomes a floral organ. The whole cycle termed the flower bud differentiation (33). The flower bud differentiation is a complicated morphological process. The interaction and synchronization of hormones and PAs trigger it from different influences, As for example, photoperiod, vernalization, nutrition, and water status (34). PAs are considered a plant growth regulator group. Several studies consistently show exogenous PAs and inhibitors of PAs synthesis can affect the differentiation of floral buds. The cycle of differentiation floral bud was enhanced by exogenous PAs, and in apical buds, the rising incidence of PAs was favorable to initiate and sustain differentiation of floral bud in chrysanthemum. In Arabidopsis, PAs was noticed to be higher in flora than in some other organ levels, and the inclusion of exogenous PAs to low-flowering plants considerably enhanced the irregular flowering response (13). PAs synthase inhibitors significantly lowered Spd rate in Arabidopsis to the growing medium and completely inhibited bolting and blooming. Only prior to moving plants to media, the bolting and flowering without inhibitors have been reestablished (35).

\subsection{Embryo development and polyamines:}

Mostly in the embryogenesis process, including such angiosperms and gymnosperms, PAs are usually considered regulators, and for embryogenesis, an enhanced PAs value is required (30). Findings have demonstrated that an excellently-maintained evolving PAs in vivo balance is needed to develop plant embryos normally. In various stages of embryonic 
development PAs vary in nature and abundance (36). Several researchers have found that PAs perform a pivotal role in triggering the cell divide and promoting regeneration of plants cell culture $(37,38)$. Usually, PAs are more prevalent in embryogenic, somatic, and zygotic immature embryos than in mature and growing embryos (39). Additional experiments using PAs synthesis inhibitors explored PAs function in plant embryogenesis. As inhibitors of PAs biosynthesis, DFMO and DFMA decreased the embryogenic response by $83 \%$ (31).

\subsection{Plant Senescence and Polyamines:}

The meristem and developing cells exhibit the maximum endogenous syntheses activity of PAs and PAs in whole plants and the senescent tissues displayed the slightest activity. Just like senescence leaves, the chlorophyll level is dramatically reduced, like ADC and ODC activities are decreasing as PAO and hydrolases activities (like ribonuclease and protease) are growing exponentially. By using exogenous PAs, all those modifications will be removed (33). It is possible to increase the PAs strength of cut flowers and postpone their senescence by exogenous Spd and Spm applications, and also improve efficiency (40). Peony research showed a lifetime prolongation and a slowing of the senescence of cut flowers with PAs synthesis inhibitor, while PAs decreased the life span and increased floral senescence (2). Table 1 and 2 showed that PAs and PAs regulating enzymes or genes play an important role of plant growth and development.

TABLE 1: Effects of polyamines on plant growth and development

\begin{tabular}{|c|c|c|c|c|}
\hline Plant species & $\begin{array}{c}\text { Polyamine } \\
\text { treatment }\end{array}$ & Effect & Outcome & Citation \\
\hline $\begin{array}{l}\text { Arabidopsis } \\
\text { thaliana }\end{array}$ & $\begin{array}{c}\text { Spd }(0.3 \text { or } 3 \mathrm{mM}) \\
\text { CHA+DFMO } \\
(4 \mathrm{mM})\end{array}$ & $\begin{array}{l}\text { Inhibitors preventing } \\
\text { bolting and flowering, } \\
\text { exogenous PAs to poorly } \\
\text { flowering plants can } \\
\text { significantly add to their } \\
\text { flowering response }\end{array}$ & $\begin{array}{l}\text { PAs promote } \\
\text { flowering }\end{array}$ & (35) \\
\hline
\end{tabular}




\begin{tabular}{|c|c|c|c|c|}
\hline $\begin{array}{l}\text { Dendranthea } \\
\text { morifolium }\end{array}$ & Spd $(0.1 \mathrm{mM} / \mathrm{L})$ & $\begin{array}{l}\text { Significantly affect } \\
\text { endogenous polyamines } \\
\text { (Spd, Spm) and } \\
\text { endogenous hormones } \\
\text { (IAA,ZR, IPA, GA) }\end{array}$ & $\begin{array}{l}\text { Accelerate the } \\
\text { process of } \\
\text { flower bud } \\
\text { differentiation }\end{array}$ & (41) \\
\hline Wheat & Spd or Spm $(1 \mathrm{mM})$ & $\begin{array}{l}\text { In wheat grains, } \\
\text { endogenous Spd, Spm, } \\
\text { ABA, and IAA contents } \uparrow \text {, } \\
\text { ETH content } \downarrow\end{array}$ & $\begin{array}{l}\text { Increased the } \\
\text { grain filling } \\
\text { rate and the } \\
\text { grain weight }\end{array}$ & (12) \\
\hline Sugarcane & Put $(500 \mu \mathrm{M})$ & $\begin{array}{l}\text { Somatic embryos in } \\
\text { embryogenic callus } \uparrow\end{array}$ & $\begin{array}{l}\text { Induces } \\
\text { somatic } \\
\text { embryo } \\
\text { development }\end{array}$ & $(42)$ \\
\hline $\begin{array}{l}\text { Seedless } \\
\text { grapevine }\end{array}$ & PAs $(0.3-3 \mathrm{mM})$ & Embryo germination rate & $\begin{array}{l}\text { Efficiency of } \\
\text { embryo rescue } \\
\text { in vitro } \uparrow\end{array}$ & (41) \\
\hline Indica rice & Put (30 mg/l) & $\begin{array}{l}\text { Spm and Spd contents } \uparrow, \\
\text { affect the expression } \\
\text { levels ofADC1gene and } \\
\text { SAMDC gene }\end{array}$ & $\begin{array}{l}\text { Improve the } \\
\text { growing state } \\
\text { and the callus } \\
\text { embryogenic } \\
\text { trait }\end{array}$ & (43) \\
\hline
\end{tabular}

TABLE 2: Genes related to polyamines on regulating plant growth

\begin{tabular}{|c|c|c|c|c|}
\hline Plant species & Gene & Effect & Outcome & Citation \\
\hline Citrus sinensis & CsPAO3 & $\begin{array}{l}\text { Over expression of } \\
\text { CsPAO3 in tobacco, Spd } \\
\text { and Spm } \downarrow \text {, Put } \uparrow\end{array}$ & $\begin{array}{l}\text { CsPAO3 plays a } \\
\text { potential role in PAs } \\
\text { back conversion }\end{array}$ & (44) \\
\hline Gossypium hirsutum L & GhPAO3 & $\begin{array}{l}\text { In transgenic } \\
\text { Arabidopsis (GhPAO3), } \\
\text { Spm } \downarrow \text {, Put } \uparrow\end{array}$ & $\begin{array}{l}\text { GhPAO3 plays a } \\
\text { potential role in the } \\
\text { conversion of Spd and } \\
\text { Spm }\end{array}$ & $(45)$ \\
\hline Transgenic rice & OsSAMDC2 & $\begin{array}{l}\text { Transcript levels of } \\
\text { OsSAMDC1, } \\
\text { OsSAMDC2, and } \\
\text { OsSAMDC4 were all } \\
\text { reduced in transgenic } \\
\text { rice, Spd, Spm, and PAs } \\
\text { oxidase activity } \downarrow\end{array}$ & $\begin{array}{l}\text { Spd and Spm are } \\
\text { essential for } \\
\text { maintenance of normal } \\
\text { plant growth, pollen } \\
\text { viability, seed setting } \\
\text { rate, grain yield and } \\
\text { stress tolerance in rice }\end{array}$ & (46) \\
\hline Transgenic tomato & $\begin{array}{l}\text { Mouse } \\
\text { ODC }\end{array}$ & $\begin{array}{l}\text { Put, Spd and Spm } \uparrow \text {, } \\
\text { ethylene, respiration rate } \\
\text { and physiological loss of } \\
\text { water } \downarrow\end{array}$ & $\begin{array}{l}\text { Enhances fruit quality } \\
\text { in tomato }\end{array}$ & $(47)$ \\
\hline Gentiana triflora & $\begin{array}{l}\text { GtSPDS or } \\
\text { GtSPMS }\end{array}$ & $\begin{array}{l}\text { The expression levels of } \\
\text { GtSPDS and GtSPMS } \\
\text { increased transiently }\end{array}$ & Hasten flowering & $(48)$ \\
\hline
\end{tabular}




\section{during vegetative to} reproductive growth phase

Pyrus betulaefolia

Medicago falcata
PbrMYB21 Modulate the PAs synthesis by regulating the ADC expression $M f E R F-1 \quad$ Up-regulates the genes associated with PAs synthesis and catabolism, promotes PAs turnover, antioxidant protection
Plays a positive role in drought tolerance

Confers cold tolerance

\section{POLYAMINE AND ABIOTIC STRESS:}

Worldwide agriculture, as a result of climate change, faces major challenges with a more irregular climate and an increasing impact of abiotic stress factors (49). With a decrease of over 50 per cent, abiotic stress is the primary cause of crop loss in worldwide (50). Different nitrogen based composites typically accumulate in plants in response to environmental stress such as amino acids (arginine, proline), amino acid compounds, amides (glutamines, asparagine) (51-53). PAs often include a wide variety of environmental challenges (Figure 3), including drought, oxidative stress, low temperature, salinity stress etc (Table 3) $(20,33,48,54,55)$. Furthermore, polyamines will become ideal targets to boost abiotic stress tolerance in plants through genetic engineering in the future. 


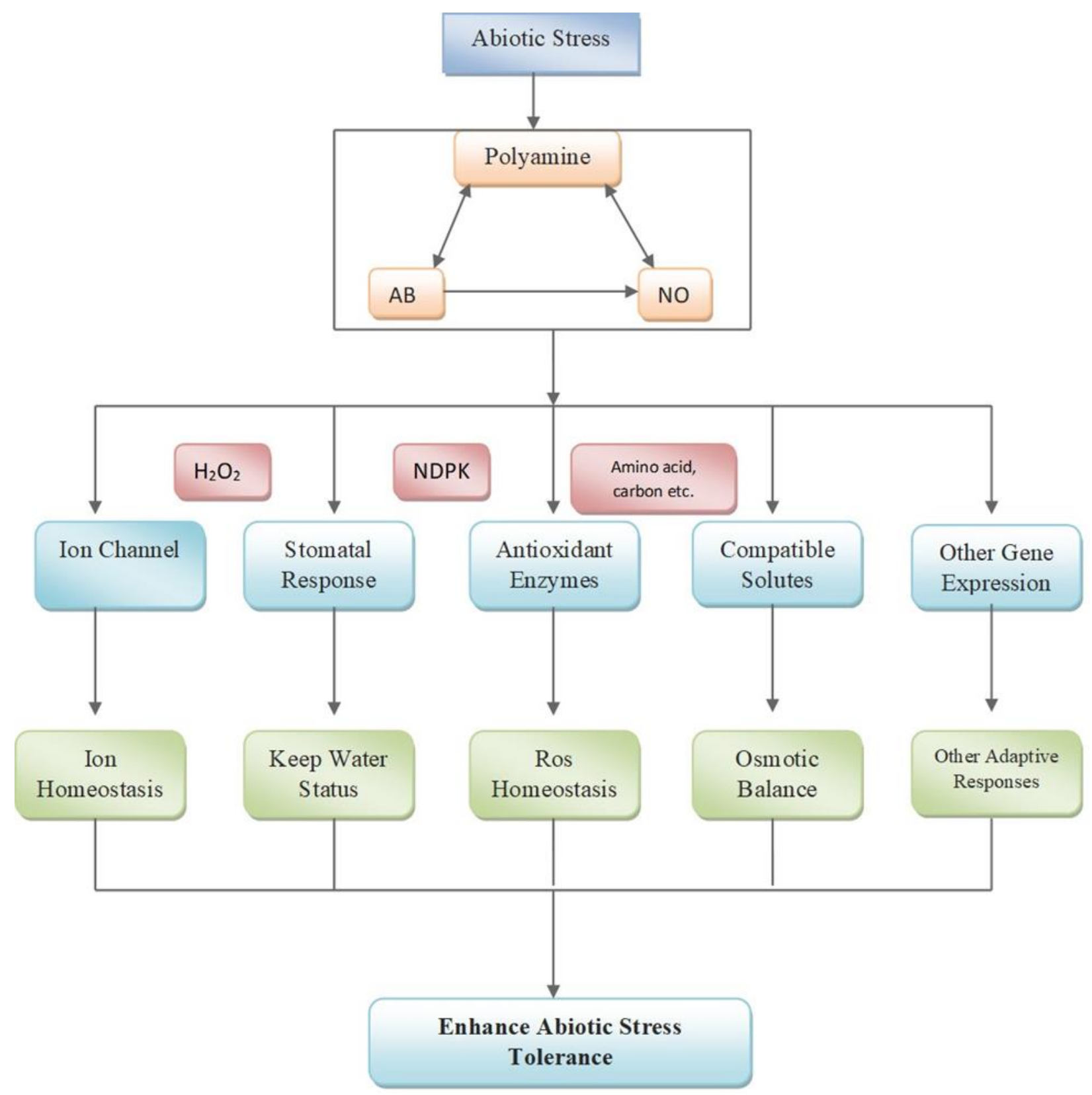

Figure 3: Possible model depicting the mechanism of polyamines involved in plant abiotic stress responses (55)

\subsection{Salinity stress:}

Salt concentration or salinity is a critical environmental restriction that has two principal ingredients: the osmotic component and the ionic component. The osmotic component related to the decline of the external osmotic potential of the soil solution and the ionic component related to the accumulation of increased salt ion (mainly $\mathrm{Na} \& \mathrm{Cl}$ ) (56). The increased degree 
of salt concentration interferes with the integrity of the cell membranes, the activity of various enzymes, and the work of the photosynthetic system (57). Plants adapt to changes in this unfavorable environment through the aggregation of low molecular weight osmolytes such as proline and PAs (58). However, there is not really a straight cut in the impact of salinity on the PAs metabolism and the process involved is usually not straight enough than osmotic stress. Diversities have been observed between and within species in PAs (Put, Spd, and $\mathrm{Spm}$ ) reactions to salt stress. For example, in rice seedlings under NaCl-stress endogenous levels of PAs (Put, Spd, and Spm) decreased, while other studies show that salinity results in the accumulation of these compounds in the same substance (49). Nonetheless, The potential role of PAs to overcome the adverse effect of salinity was also observed by researchers (59).

\subsection{Cold Stress}

In plants Cold stress is characterized by three terms: freezing, chilling and suboptimal temperature. Freezing is a term considered until the air temperature is below $0^{\circ} \mathrm{C}$, although agro-meteorological observers would use the same concept for ranges from 2 to $3^{\circ} \mathrm{C}$ because plants cause damage at these temperatures. The word chilling is associated for temperatures between $0^{\circ} \mathrm{C}$ and the minimum growth temperature. In addition, the range between the minimum temperature of growth and the optimum temperature of growth is known as suboptimal $(60,61)$. Injury despite the cold induces changes of the membrane structure as well as the chilling injury tends to involve a phase shift in the molecular inventory of the membrane lipids (62). Cold therapy has been demonstrated to affect Put rates, which is also in line via a rise in Arginine Decarboxylase (ADC) gene inductibility (ADC1, ADC2 and SAMDC2) (63). A results observed that Put and ABA are incorporated into a feedback loop, where ABA and Put mutually induce biosynthesis to respond to abiotic stress (32). 


\subsection{Drought Stress}

The two major abiotic stresses in agriculture are salt and drought stress and a reduced water states are a common effect of all of these. Increased PAs levels can play an important role in adapting to saline conditions in plants faced with drought stress $(46,64)$. In the event of drought stress, the concentration of $B$-alanine in the result of polyamine degradation has never been altered while the GABA levels have evidently enhanced $(6,65)$. The pool size of arginine, the principal polyamine biosynthesis substrate, has risen under drought conditions, showing a lack of substrates (66). The expression of ADC2 was up regulated, apart from the two most vulnerable cultivars, in response to the drought stress. That was consistent with the Arabidopsis and Mustard findings (63).

\subsection{Osmosis stress:}

The study reported that osmotic with distinctly diverse assimilation paths, including sorbitol, mannitol, proline, beta and sucrose, each stimulate an increase in Put (67). The results of this study show a regulation of ADC biosynthesis over osmotic stress. Osmotic treatments with sorbitol triggered increased Put and ADC levels in detached oat leaves, while other Spd and Spm display a significant reduction $(31,68)$. Tiburcio et al (1995) noticed that they begin losing chlorophyll and senescence while peeled oat leaves are incubated in the dark with sorbitol. Including Spm in the incubation medium could delay senescence.

\subsection{Oxidative Stresses}

During oxidative stress of plants, polyamines play a complicated role (69). First on, PAs may also enhance the potential of various anti-oxidant enzymes in plants, just so oxidant stress due to diverse environmental factors can actually be controlled. Pretreated maize leaves containing Spm and put display improved tolerance for paraquat-induced oxidative stress (70). In contrast, PAs constitute sources for reactive oxygen types and can lead to stimulation of antioxidant defense responses since their catabolism produce strong $\mathrm{H}_{2} \mathrm{O}_{2}$ (37). and $\mathrm{H}_{2} \mathrm{O}_{2}$ oxidizers produced through the catabolism of PA (54). ROS regarded by aggregation of 
noxious molecules $\mathrm{O}_{2}^{-}, \mathrm{H}_{2} \mathrm{O}_{2}$, and $\mathrm{OH}^{-}$in tissues is a normal plant association with abiotic stress that is capable of injuring plant cell membranes as well as macro molecules (71). PAO and ROS production is closely linked to PAO catabolic mechanisms (25) that are associated to plant defense as well as abiotic stress responses (72).

\subsection{Thermal stress:}

In case of heat stress, plants are able to synthesize different PAs long chains (caldine, thermine). Such rare long-chained PAs in bacteria are apparently important for the subsequent protein synthesis at high-temperature (44). A rise in ADC and PAO activities was recorded in heat tolerant rice crops (73). The study found that heat stress tolerance, ADC and PAO are correlated (72).

TABLE 3: Polyamines genes that can be expressed in plants for Abiotic stress tolerance

\begin{tabular}{|c|c|c|c|}
\hline Plant & $\begin{array}{l}\text { Gene over } \\
\text { expressed }\end{array}$ & Response & Reference \\
\hline Oryza sativa & $\mathrm{ADC}$ & Salt tolerance & (73) \\
\hline Brassica juncea & $\mathrm{ADC}$ & Chilling and salt & (74) \\
\hline Oryza sativa & $\mathrm{ADC} 1, \mathrm{ADC} 2$ & Drought tolerance & (75) \\
\hline Arabidopsis thaliana & $\mathrm{ADC} 1, \mathrm{ADC} 2$ & Freezing & (34) \\
\hline Malus domestica & $\mathrm{ADC}$ & $\begin{array}{l}\text { Chilling, Salt and } \\
\text { Dehydration }\end{array}$ & (76) \\
\hline Oryza sativa & $\mathrm{ADC}$ & Chilling & $(48)$ \\
\hline Arabidopsis thaliana & At ADC2 & Salt tolerance & $(63)$ \\
\hline Solanum melongena & $\mathrm{ADC}$ & $\begin{array}{l}\text { Chilling, Salt and } \\
\text { Dehydration }\end{array}$ & $(77)$ \\
\hline Zea maize & $\mathrm{ADC}$ & Salt & $(78)$ \\
\hline Malus sylvestris & MdSAMDC2 & Cold and salt & $(76)$ \\
\hline Pyrus communis & MdSAMDC3 & salt & $(7)$ \\
\hline Sweet potato & $\begin{array}{l}\text { SPDS cDNA from } \\
\text { Cucurbita ficifolia }\end{array}$ & Increase in Spd & (79) \\
\hline Pyrus communis & MdSPDS1 & $\begin{array}{l}\text { Salt, Heavy metal and } \\
\text { osmotic stress }\end{array}$ & $(8)$ \\
\hline
\end{tabular}




\section{POLYAMINE AND PLANT RESPONSES TO BIOTIC STRESSES}

The plant biotic stress resistance is also associated with PAs metabolism induction of genes as well as with the development of greater PAs concentrations. It was already proven by analyzing two Barley genotypes with varying tolerance to B. graminis f. sp. hordei (Bgh) (60). During this case, a significant enhancement in the independent, as well as the conjugated type of Put and Spd and the expression of PAs biosynthetic and catabolic genes was observed when the fungi were examined. In addition, Put accumulation in tomato plants have recently times been shown to enhance tolerance to bacterial inflammation due to high NH4 availability (80). The use of genetically modified plants provides further evidence that higher PA levels are linked to biotic stress tolerances. Throughout this phenomenon, plants that express the human gene SAMDC accumulate Spd and Spm and also have a higher tolerance to pathogens (78).

\subsection{Plant-pathogen interaction:}

Polyamines have a biotic stress defense mechanism (13), especially pathogens (Figure 4) . Initial attempts have found that PAs particularly Spm develops in infected leaves in cooperative interactions between barley and Puccinia hordei (brown roost fungus) (44). Hypersensitive response to the Nicotiana tobacum cells that contain the resistance gene and activates cell death is a powerful defense against the tobacco mosaic virus (78). It is difficult to establish the contribution of PAs in both plants and pathogens to the accumulation of PAs in infected organs. Nonetheless, it is possible to control fungal plant diseases by specific inhibitors of polyamines biosynthesis that is the most important and extensive development in this field $(67,81)$. A further significant finding on PAs effects in the biotic stress response signal pathway has been suggested. $\mathrm{H}_{2} \mathrm{O}_{2}$ accumulation due to $\mathrm{Spm} / \mathrm{Spd}$ induction as a result of the PAs catabolism and nitric oxides, an important signaling function in plant-pathogen interactions (82). 


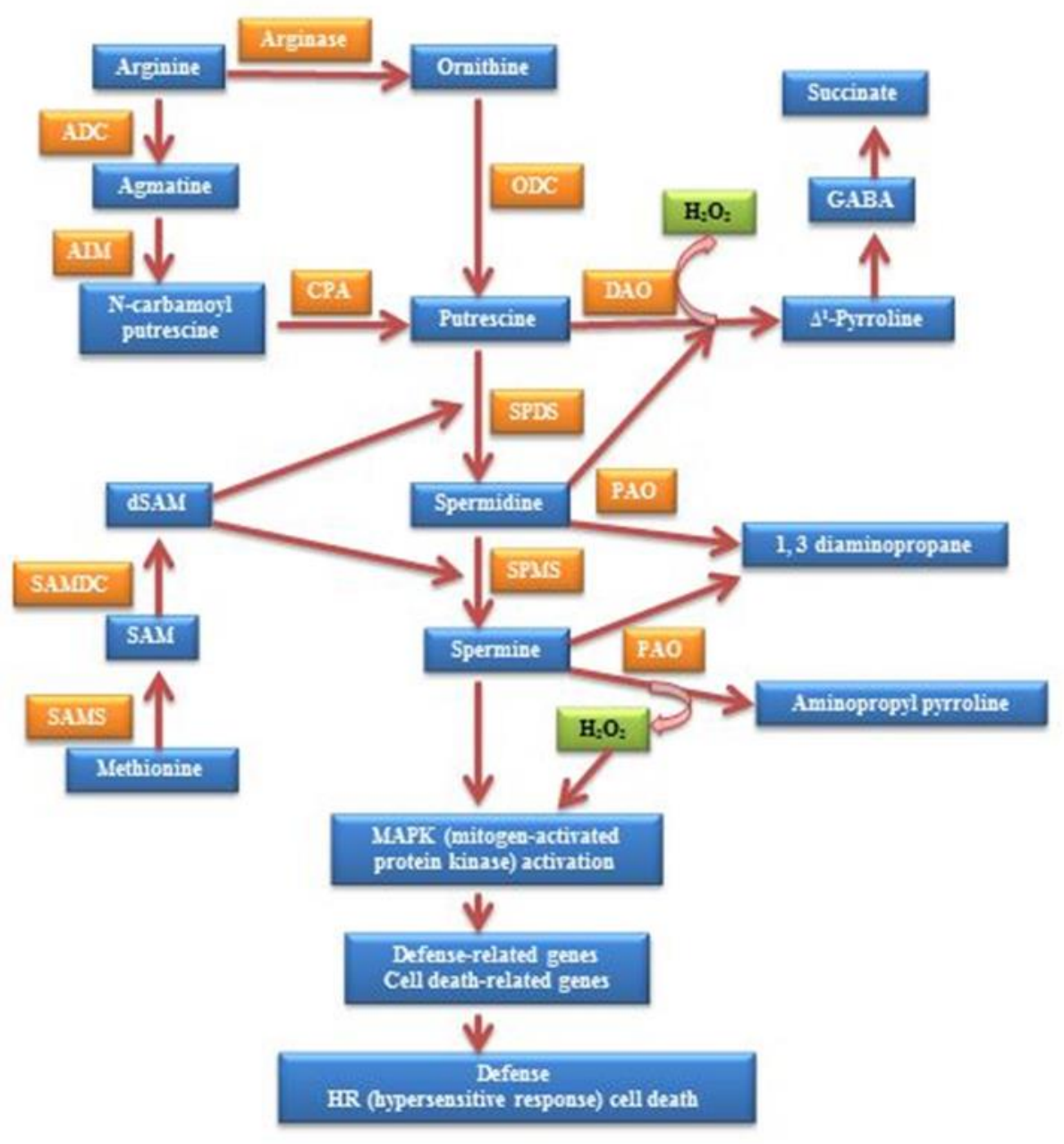

Figure 4: The hypothetical role of PAs in plant survival against pathogens (13).

\subsection{Plants-fungal interaction:}

While changes in the metabolism of polyamines in plant responses due to abiotic strain have been and continue to be of considerable interest, relatively least research has been done on polyamines and to microbial infections in plants $(9,83)$. The most important documentation of polyamine levels is Greenland and Lewis that have been affected by pathogenic infection. The barley infected with Puccinia hordei bio trophic fungal pathogens showed that rust infection contributed to a six to seven-fold increase in the concentrations of spermidine in healthy leaf tissue (16). Research demonstrates that powdery mildew fungus B. graminis f. sp. hordei (Bgh) has increased the concentration of Putrescine, Spermidine, and Spermine in 
barley leaves. Researchers also found that the activity of polyamines biosynthetic enzymes (ADC, ODC, and AdoMetDC) was increased by mildew infection (80). Through the addition of this analysis, Walters and Wylie (43) showed that in the region immediately surrounded by the fungal pustula the greatest increases in polyamine and activities of ADC and ODC often occur (Figure 5). Machatschke et al (1990) showed that there were no variations in the polyamine level for wheat resistant to the black stem rust fungus Puccinia graminis f.sp.tritici .Working on the relationship between sugarcane and smut fungus Ustilago scitamineae. Legaz et al (2007) showed that concentrations of free and conjugated forms of Putrescine and Spermidine decreased in infected leaves, and that sperm has increased freely and in conjugation (84). It was also important to note that the polyamine levels were decreased in Rhizopus stolonifer fungus-infected tomatoes and these improvements were correlated with decreases in ODC and ADC activities (85).

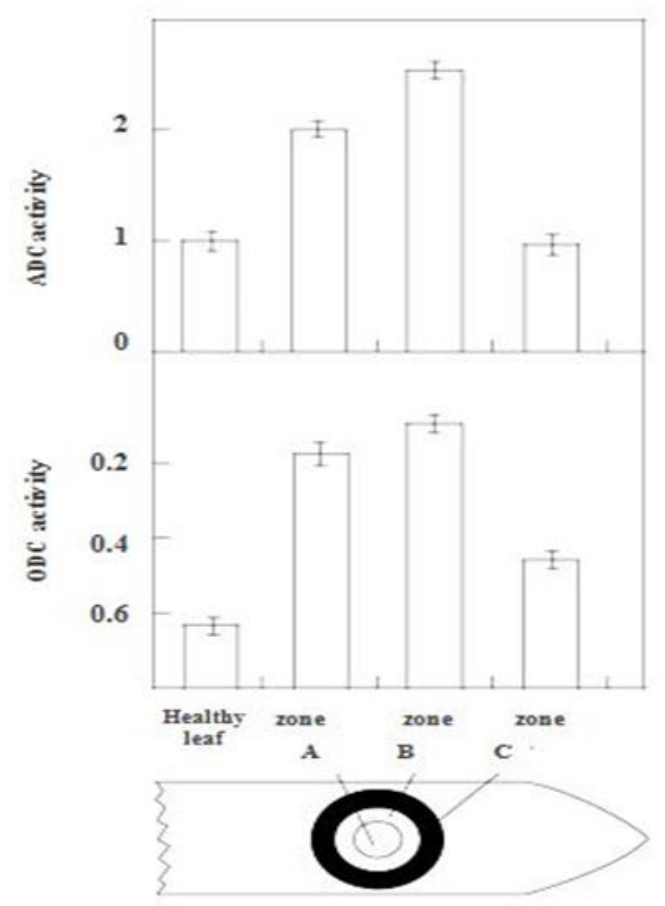

Figure 5: The activities $\left[\mathrm{nmol}{ }^{14} \mathrm{CO}_{2}\left(\mathrm{mg}\right.\right.$ protein) $\left.{ }^{\ddot{y} 1} \mathrm{~h}{ }^{\ddot{1} 1}\right]$ of arginine decarboxylase (a) and ornithine decarboxylase (b) in healthy leaves and in discrete regions of mildewed barley 
leaves. Zone A, pustule; Zone B, region up to $5 \mathrm{~mm}$ from pustule boundary; Zone $\mathrm{C}$, region up to $5 \mathrm{~mm}$ from boundary of Zone B. Vertical bars represent SEM of four replicates (43).

\subsection{Plant-mycorrhizal interaction:}

Mostly in the environment, root construction and formation of root and root structures, interactions between root tissue and the surrounding biotic environment, in particular, microorganisms are highly dependent. Therefore the interactions between plants and mycorrhizas are not very known and the function of APs is less investigated in symbiotic relationships (86). The symbiosis of mycorrhizae has shown Kytoviita and Sarjala to increase putrescin in the root of Scot Pine. Exogenous Put in arbuscular mycorrhizae, which increases colony of pea roots, has been confirmed to be present (77). PAs have been demonstrated to have a Arbuscular mycorrhizal infection of pea roots, and Glomus intraradices have been proposed to play a significant role in the first phases of infection (63). Studies show that connections between symbiotic and non-symbiotic roots have varying amounts of polyamines and that PAs can develop an appropriate carbon sink environment for the symbiotics as a result of photoassimilates fixation (87). But the roles of PAs remain unusual in the plant/ mycorrhizal associations and wait for further investigations.

\subsection{Plant-virus interaction:}

It is understood for some time that viral host tissue infection contributes to significant buildups of polyamines, for example, Turnip yellow mosaic virus (TYMV) infection $(88,89)$. A few other investigator have proposed regulatory roles in viral replication for this polyamines (90) and strangely, Balintand Cohen (2003) has showed that the formation of new virus particles contains primarily newly synthesized Spm and Spd in Turpin protoplasts infected with TYMV (15). Tobacco cv Research Samsun NN showed that polyamine levels in tobacco plants have accumulates of high levels of Put and Spd in the necrotic region of leaves and 
lesion formation by the infection with tobacco mosaic virus and has been revealed (88). These were proposed that the production of necrotic lesions of leaves requires large amounts of polyamines. Lower lesion formation by inoculating TMV 90 percent in tobacco leaf disks. HCAAs are shown to be actively involved in TMV resistance. Thereby, PAs and HCAAs are responsible for the survival of viral replication, as they are hypersensitive to TMV (83).

\subsection{Defense of plant:}

The synchronization and environmental equilibrium of internal processes in plants are related to the stimulation of plant cells. In addition, the endogenous induction of the expression pathway and pathogen-related (PR) proteins, as well as resistance to TMV in the tobacco plants, was documented in the case of Spm accumulated in the apoplast cells after lesion formation (54). Nicotiana tabacum leaves were reported to use Spm that led to the malfunctioning of mitochondria, increased marker gene (HR, hypersensitive reaction), mitogenic activated protein kinases (MAPKs), and programmed cell death (PCD) (91). Induced by the development of a lesion in tobacco leaves, the pathogen-related protein (PRPs) accumulation of a large quantity of Spm in cells and resistance against the tobacco mosaic virus. Ultimately, Spm triggers two protein kinases, namely salicylic acid protein kinases and wound protein kinases as well as genes involved in the defense of plant protection (92). Nonetheless, more work is needed in order for PAs to establish a plant defense response mechanism.

\section{Conclusion}

Different food/vegetable crops in the worlds that are differently affected by biotic and abiotic stresses and their productivity is decreasing every year by global environmental changes (GEC). GEC causes salinity, drought, flooding, soil acidification, soil salinization, extremely low and high temperatures, pathogens, fungal, mycorrhiza, virus and other adverse environmental conditions. These GEC factors directly or indirectly affect plants production. Thus, it is very necessary to improvement stress tolerant and diseases resistant plant variety. 
Polyamines have a lot of physiological and cellular functions such as seed germination, cell division, somatic embryogenesis and differentiation, development of flowers and fruits, dormancy breakdown of tubers, protect phosynthetic apparatus. To perceive the function of polyamines in growth and differentiation, the version of plant 'PAs modulation' has been elucidated. To find out the exogenous and endogenous PAs level, and their defense mechanisms or ion channels on plants. Therefore, a lot of recent biological techniques required specially molecular biology and genetic engineering techniques (microarray, transcriptomics, metabolomics, proteomics, reverse genetics approaches) for the improvement of PAs transgenic plant to stress tolerant and diseases resistant and their functions will be implicate in plant sciences.

\section{ACKNOWLEDGEMENT}

Authors are very much thankful to the Department of Biotechnology and Genetic Engineering, Islamic University Kushtia-7003, Bangladesh for research facilities and other logistic supports.

\section{FUNDING}

No funding was received for this study.

\section{AUTHOR CONTRIBUTIONS}

MAI planned and designed the project. MAI, MAM, MLR and MMR performed the literature reviews. MAI, MAM, MLR, MMR, MLK, MAH wrote the manuscript. MAM, MLR, MMR illustrated the figures and table. MAI, MAM and MAH checked and revised the manuscript for necessary changes in format, grammar and English standard. All authors read and agreed on the final version of the manuscript. 


\section{CONFLICTS OF INTEREST}

Authors declared that they have no conflict of interest.

\section{References:}

1. Walters D. Resistance to plant pathogens: possible roles for free polyamines and polyamine catabolism. New Phytol. 2003;159(1):109-15.

2. Mustafavi SH, Badi HN, Sekara A, Mehrafarin A, Janda T, Ghorbanpour M, et al. Polyamines and their possible mechanisms involved in plant physiological processes and elicitation of secondary metabolites. Acta Physiol Plant. 2018;40(6):102.

3. Karamanou M, Poulakou-Rebelakou E, Tzetis M, Androutsos G. Anton van Leeuwenhoek (1632-1723): father of micromorphology and discoverer of spermatozoa. Rev Argent Microbiol. 2010;42(4):311-4.

4. Uehara Y, Takahashi Y, Berberich T, Miyazaki A, Takahashi H, Matsui K, et al. Tobacco ZFT1, a transcriptional repressor with a Cys 2/His 2 type zinc finger motif that functions in spermine-signaling pathway. Plant Mol Biol. 2005;59(3):435-48.

5. Zhu M-Y, Iyo A, Piletz JE, Regunathan S. Expression of human arginine decarboxylase, the biosynthetic enzyme for agmatine. Biochim Biophys Acta (BBA)General Subj. 2004;1670(2):156-64.

6. Bagni N, Tassoni A. Biosynthesis, oxidation and conjugation of aliphatic polyamines in higher plants. Amino Acids. 2001;20(3):301-17.

7. Lightfoot HL, Hall J. Endogenous polyamine function - the RNA perspective. Nucleic Acids Res. 2014;42(18):11275-90. 
8. Malmberg RL, Watson MB, Galloway GL, Yu W. Molecular genetic analyses of plant polyamines. CRC Crit Rev Plant Sci. 1998;17(2):199-224.

9. Bouchereau A, Aziz A, Larher F, Martin-Tanguy J. Polyamines and environmental challenges: recent development. Plant Sci. 1999;140(2):103-25.

10. Kumar A, Taylor M, Altabella T, Tiburcio AF. Recent advances in polyamine research. Trends Plant Sci. 1997;2(4):124-30.

11. Jang SJ, Wi SJ, Choi YJ, An G, Park KY. Increased polyamine biosynthesis enhances stress tolerance by preventing the accumulation of reactive oxygen species: T-DNA mutational analysis of Oryza sativa lysine decarboxylase-like protein 1. Mol Cells. $2012 ; 34(3): 251-62$.

12. Yang J, Zhang J, Liu K, Wang Z, Liu L. Involvement of polyamines in the drought resistance of rice. J Exp Bot. 2007;58(6):1545-55.

13. Islam MA, Maitra P, Mandal D. A Review on Polyamines and Biotic Stresses in Plants. Asian J Appl Sci. 2018;6(5).

14. Mehta RA, Cassol T, Li N, Ali N, Handa AK, Mattoo AK. Engineered polyamine accumulation in tomato enhances phytonutrient content, juice quality, and vine life. Nat Biotechnol. 2002;20(6):613-8.

15. Bailey BA, Strem MD, Bae H, De Mayolo GA, Guiltinan MJ. Gene expression in leaves of Theobroma cacao in response to mechanical wounding, ethylene, and/or methyl jasmonate. Plant Sci. 2005;168(5):1247-58.

16. Greenland AJ, Lewis DH. Amines in barley laves infected by brown rust and their possible relevance to formation of 'green islands.' New Phytol. 1984;96(2):283-91. 
17. Torrigiani P, Rabiti AL, Bortolotti C, Betti L, Marani F, Canova A, et al. Polyamine synthesis and accumulation in the hypersensitive response to TMV in Nicotiana tabacum. New Phytol. 1997;135(3):467-73.

18. Eguchi S, Numaguchi K, Iwasaki H, Matsumoto T, Yamakawa T, Utsunomiya H, et al. Calcium-dependent epidermal growth factor receptor transactivation mediates the angiotensin II-induced mitogen-activated protein kinase activation in vascular smooth muscle cells. J Biol Chem. 1998;273(15):8890-6.

19. Docimo T, Reichelt M, Schneider B, Kai M, Kunert G, Gershenzon J, et al. The first step in the biosynthesis of cocaine in Erythroxylum coca: the characterization of arginine and ornithine decarboxylases. Plant Mol Biol. 2012;78(6):599-615.

20. Rider JE, Hacker A, Mackintosh CA, Pegg AE, Woster PM, Casero RA. Spermine and spermidine mediate protection against oxidative damage caused by hydrogen peroxide. Amino Acids. 2007;33(2):231-40.

21. Hanfrey C, Sommer S, Mayer MJ, Burtin D, Michael AJ. Arabidopsis polyamine biosynthesis: absence of ornithine decarboxylase and the mechanism of arginine decarboxylase activity. Plant J. 2001;27(6):551-60.

22. Grossi M, Phanstiel O, Rippe C, Swärd K, Alajbegovic A, Albinsson S, et al. Inhibition of polyamine uptake potentiates the anti-proliferative effect of polyamine synthesis inhibition and preserves the contractile phenotype of vascular smooth muscle cells. J Cell Physiol. 2016;231(6):1334-42.

23. Vuosku J, Karppinen K, Muilu-Mäkelä R, Kusano T, Sagor GHM, Avia K, et al. Scots pine aminopropyltransferases shed new light on evolution of the polyamine biosynthesis pathway in seed plants. Ann Bot. 2018;121(6):1243-56. 
24. Gupta K, Dey A, Gupta B. Plant polyamines in abiotic stress responses. Acta Physiol Plant. 2013;35(7):2015-36.

25. Bianchi M, Polticelli F, Ascenzi P, Botta M, Federico R, Mariottini P, et al. Inhibition of polyamine and spermine oxidases by polyamine analogues. FEBS J. 2006;273(6):1115-23.

26. Planas-Portell J, Gallart M, Tiburcio AF, Altabella T. Copper-containing amine oxidases contribute to terminal polyamine oxidation in peroxisomes and apoplast of Arabidopsis thaliana. BMC Plant Biol. 2013;13(1):1-13.

27. Cohen SS, others. Guide to the Polyamines. Oxford University Press; 1998.

28. Flores HE, Filner P. Metabolic relationships of putrescine, GABA and alkaloids in cell and root cultures of Solanaceae. In: Primary and secondary metabolism of plant cell cultures. Springer; 1985. p. 174-85.

29. Moschou PN, Sanmartin M, Andriopoulou AH, Rojo E, Sanchez-Serrano JJ, Roubelakis-Angelakis KA. Bridging the gap between plant and mammalian polyamine catabolism: a novel peroxisomal polyamine oxidase responsible for a full backconversion pathway in Arabidopsis. Plant Physiol. 2008;147(4):1845-57.

30. Freitas VS, de Souza Miranda R, Costa JH, de Oliveira DF, de Oliveira Paula S, de Castro Miguel E, et al. Ethylene triggers salt tolerance in maize genotypes by modulating polyamine catabolism enzymes associated with $\mathrm{H} 2 \mathrm{O} 2$ production. Environ Exp Bot. 2018;145:75-86.

31. Ahmad P, Kumar A, Gupta A, Hu X, Azooz MM, Sharma S, et al. Polyamines: role in plants under abiotic stress. In: Crop production for agricultural improvement. Springer; 2012. p. 491-512. 
32. Tiburcio AF, Altabella T, Bitrián M, Alcázar R. The roles of polyamines during the lifespan of plants: from development to stress. Planta. 2014;240(1):1-18.

33. Duan J, Li J, Guo S, Kang Y. Exogenous spermidine affects polyamine metabolism in salinity-stressed Cucumis sativus roots and enhances short-term salinity tolerance. J Plant Physiol. 2008;165(15):1620-35.

34. Cuevas JC, López-Cobollo R, Alcázar R, Zarza X, Koncz C, Altabella T, et al. Putrescine as a signal to modulate the indispensable ABA increase under cold stress. Plant Signal Behav. 2009;4(3):219-20.

35. Schmidt D, Applewhite DR, Foster CJ, Stoddard JF, Dubrofsky S. Scoring a Musical Performance Involving Multiple Parts. Google Patents; 2010.

36. Soltys D, Krasuska U, Bogatek R, Gniazdowska A. Allelochemicals as bioherbicides_-present and perspectives. In: Herbicides-Current research and case studies in use. IntechOpen; 2013.

37. Minocha R, Majumdar R, Minocha SC. Polyamines and abiotic stress in plants: a complex relationship1. Front Plant Sci. 2014;5:175.

38. Barnes HA. Sections 2.4. 4 \& 2.4. 5 pp 27-30 in An introduction to rheology, Eds. HA Barnes, JF Hutton, K. Walters, Vol 3 Rheology Series. Elsevier BV, Amsterdam; 1989.

39. Kevers C, Le Gal N, Monteiro M, Dommes J, Gaspar T. Somatic embryogenesis of Panax ginseng in liquid cultures: a role for polyamines and their metabolic pathways. Plant Growth Regul. 2000;31(3):209-14.

40. Islam MA, PANG J, MENG F, LI Y, Ning XU, Chao Y, et al. Putrescine, spermidine, 
and spermine play distinct roles in rice salt tolerance. J Integr Agric. 2020;19(3):64355.

41. $\mathrm{Hu} X, \mathrm{Xu} Z, \mathrm{Xu} W, \mathrm{Li}$ J, Zhao N, Zhou Y. Application of \$ $\$$-aminobutyric acid demonstrates a protective role of polyamine and GABA metabolism in muskmelon seedlings under Ca (NO3) 2 stress. Plant Physiol Biochem. 2015;92:1-10.

42. Machatschke S, Kamrowski C, Moerschbacher BM, Reisener H-J. Polyamine levels in stem rust infected wheat leaves and effects of alpha-difluoromethylornithine on fungal infection. Physiol Mol Plant Pathol. 1990;36(6):451-9.

43. Hussain T, Tan B, Ren W, Rahu N, Dad R, Kalhoro DH, et al. Polyamines: therapeutic perspectives in oxidative stress and inflammatory diseases. Amino Acids. 2017;49(9):1457-68.

44. Kessler RC, Berglund P, Demler O, Jin R, Koretz D, Merikangas KR, et al. The epidemiology of major depressive disorder: results from the National Comorbidity Survey Replication (NCS-R). Jama. 2003;289(23):3095-105.

45. Ouyang J, Song C, Chen D. Research progress on heat-tolerance mechanism and transports of polyamfines in plant. Mol Plant Breed. 2017;15:3286-94.

46. Chen D, Shao Q, Yin L, Younis A, Zheng B. Polyamine function in plants: metabolism, regulation on development, and roles in abiotic stress responses. Front Plant Sci. 2019;9:1945.

47. Kumar N, Gautam A, Dubey AK, Ranjan R, Pandey A, Kumari B, et al. GABA mediated reduction of arsenite toxicity in rice seedling through modulation of fatty acids, stress responsive amino acids and polyamines biosynthesis. Ecotoxicol Environ Saf. 2019;173:15-27. 
48. Imai A, Matsuyama T, Hanzawa Y, Akiyama T, Tamaoki M, Saji H, et al. Spermidine synthase genes are essential for survival of Arabidopsis. Plant Physiol. 2004;135(3):1565-73.

49. Aryal JP, Sapkota TB, Khurana R, Khatri-Chhetri A, Jat ML, others. Climate change and agriculture in South Asia: adaptation options in smallholder production systems. Environ Dev Sustain. 2019;1-31.

50. Alcázar R, Marco F, Cuevas JC, Patron M, Ferrando A, Carrasco P, et al. Involvement of polyamines in plant response to abiotic stress. Biotechnol Lett. 2006;28(23):186776.

51. Sharma SS, Dietz K-J. The significance of amino acids and amino acid-derived molecules in plant responses and adaptation to heavy metal stress. J Exp Bot. 2006;57(4):711-26.

52. Chen THH, Murata N. Glycinebetaine: an effective protectant against abiotic stress in plants. Trends Plant Sci. 2008;13(9):499-505.

53. Munns R. Genes and salt tolerance: bringing them together. New Phytol. 2005;167(3):645-63.

54. Kusano T, Yamaguchi K, Berberich T, Takahashi Y. Advances in polyamine research in 2007. J Plant Res. 2007;120(3):345-50.

55. Shi H, Chan Z. Improvement of plant abiotic stress tolerance through modulation of the polyamine pathway. J Integr Plant Biol. 2014;56(2):114-21.

56. Saxena SC, Kaur H, Verma P, Petla BP, Andugula VR, Majee M. Osmoprotectants: potential for crop improvement under adverse conditions. In: Plant Acclimation to 
Environmental Stress. Springer; 2013. p. 197-232.

57. Zhu B, Su J, Chang M, Verma DPS, Fan Y-L, Wu R. Overexpression of a $\Delta 1$ pyrroline-5-carboxylate synthetase gene and analysis of tolerance to water-and saltstress in transgenic rice. Plant Sci. 1998;139(1):41-8.

58. Flores HE. Changes in polyamine metabolism in response to abiotic stress. Biochem Physiol Polyam Plants. 1991;213-28.

59. Mutlu F, Bozcuk S. Effects of salinity on the contents of polyamines and some other compounds in sunflower plants differing in salt tolerance. Russ J Plant Physiol. 2005;52(1):29-34.

60. Menéndez AB, Rodriguez AA, Maiale SJ, Rodriguez KM, Jimenez BJF, Ruiz OA. Polyamines contribution to the improvement of crop plants tolerance to abiotic stress. In: Crop improvement under adverse conditions. Springer; 2013. p. 113-36.

61. Sannazzaro AI, Álvarez CL, Menéndez AB, Pieckenstain FL, Albertó EO, Ruiz OA. Ornithine and arginine decarboxylase activities and effect of some polyamine biosynthesis inhibitors on Gigaspora rosea germinating spores. FEMS Microbiol Lett. 2004;230(1):115-21.

62. Lyons JM, Raison JK. Oxidative activity of mitochondria isolated from plant tissues sensitive and resistant to chilling injury. Plant Physiol. 1970;45(4):386-9.

63. Urano K, Yoshiba Y, Nanjo T, Igarashi Y, Seki M, Sekiguchi F, et al. Characterization of Arabidopsis genes involved in biosynthesis of polyamines in abiotic stress responses and developmental stages. Plant Cell Environ. 2003;26(11):1917-26.

64. Tun C-J, Sheu J-K, Lee M-L, Hu C-C, Hsieh C-K, Chi G-C. Effects of thermal 
annealing on Al-doped $\mathrm{ZnO}$ films deposited on p-type gallium nitride. J Electrochem Soc. 2006;153(4):G296.

65. Kuehn GD, Rodriguez-Garay B, Bagga S, Phillips GC. Novel occurrence of uncommon polyamines in higher plants. Plant Physiol. 1990;94(3):855-7.

66. Do PT, Degenkolbe T, Erban A, Heyer AG, Kopka J, Köhl KI, et al. Dissecting rice polyamine metabolism under controlled long-term drought stress. PLoS One. 2013;8(4):e60325.

67. Flores HE, Galston AW. Osmotic stress-induced polyamine accumulation in cereal leaves: I. Physiological parameters of the response. Plant Physiol. 1984;75(1):102-9.

68. Gupta K, Dey A, Gupta B. Polyamines and their role in plant osmotic stress tolerance. Clim Chang plant abiotic Stress Toler. 2013;1053-72.

69. de Oliveira LF, Navarro BV, Cerruti GV, Elbl P, Minocha R, Minocha SC, et al. Polyamine-and amino acid-related metabolism: the roles of arginine and ornithine are associated with the embryogenic potential. Plant Cell Physiol. 2018;59(5):1084-98.

70. Durmu N, Kadioğlu A. Spermine and putrescine enhance oxidative stress tolerance in maize leaves. Acta Physiol Plant. 2005;27(4):515-22.

71. Alizade-Dashqapu M, Esna-Ashari M, Hajiloo J, Asgharpur M. Effect of $\mathrm{CaCl} 2$ and exogenous putrescine on post-harvest life and quality of peach (Prunus persica (L.) Batsch) fruit, cv. ‘JH Hale.' Fruit, Veg Cereal Sci Biotechnol. 2011;5:40-5.

72. Roy P, Niyogi K, Sengupta DN, Ghosh B. Spermidine treatment to rice seedlings recovers salinity stress-induced damage of plasma membrane and PM-bound $\mathrm{H}+-$ ATPase in salt-tolerant and salt-sensitive rice cultivars. Plant Sci. 2005;168(3):583-91. 
73. Roy M, Ghosh B. Polyamines, both common and uncommon, under heat stress in rice (Oryza sativa) callus. Physiol Plant. 1996;98(1):196-200.

74. Mo H, Pua E-C. Up-regulation of arginine decarboxylase gene expression and accumulation of polyamines in mustard (Brassica juncea) in response to stress. Physiol Plant. 2002;114(3):439-49.

75. Capell T, Bassie L, Christou P. Modulation of the polyamine biosynthetic pathway in transgenic rice confers tolerance to drought stress. Proc Natl Acad Sci. 2004;101(26):9909-14.

76. Wen X-P, Pang X-M, Matsuda N, Kita M, Inoue H, Hao Y-J, et al. Over-expression of the apple spermidine synthase gene in pear confers multiple abiotic stress tolerance by altering polyamine titers. Transgenic Res. 2008;17(2):251-63.

77. Prabhavathi VR, Rajam MV. Polyamine accumulation in transgenic eggplant enhances tolerance to multiple abiotic stresses and fungal resistance. Plant Biotechnol. 2007;24(3):273-82.

78. Jiménez Bremont JF, Marina M, Guerrero-Gonzalez M de la L, Rossi FR, SánchezRangel D, Rodrl'liguez-Kessler M, et al. Physiological and molecular implications of plant polyamine metabolism during biotic interactions. Front Plant Sci. 2014;5:95.

79. Igarashi K, Kashiwagi K. Polyamines: mysterious modulators of cellular functions. Biochem Biophys Res Commun. 2000;271(3):559-64.

80. Walters DR. Polyamines in plant-microbe interactions. Physiol Mol Plant Pathol. 2000;57(4):137-46.

81. Galston AW, Weinstein LH. Control of phytopathogens by inhibitors of polyamine 
biosynthesis. In: Progress in Polyamine Research. Springer; 1988. p. 589-99.

82. Romero-Puertas MC, Rodrl'liguez-Serrano M, Corpas FJ, Gomez M del, Del Rio LA, Sandalio LM. Cadmium-induced subcellular accumulation of $\mathrm{O} 2 \cdot-$ and $\mathrm{H} 2 \mathrm{O} 2$ in pea leaves. Plant Cell Environ. 2004;27(9):1122-34.

83. Martin-Tanguy J, Martin C, Gallet M, Vernoy R. Comptes rendus de l'académie des Sciences. Paris. 1976;282:2231-4.

84. Legaz ME, Armas R de, Piñón D, Vicente C. Relationships between phenolicsconjugated polyamines and sensitivity of sugarcane to smut (Ustilago scitaminea). J Exp Bot. 1998;49(327):1723-8.

85. Bakanashvili M, Barkai-Golan R, Kopeliovitch E, Apelbaum A. Polyamine biosynthesis in Rhizopus-infected tomato fruits: possible interaction with ethylene. Physiol Mol Plant Pathol. 1987;31(1):41-50.

86. Kytöviita M-M, Sarjala T. Effects of defoliation and symbiosis on polyamine levels in pine and birch. Mycorrhiza. 1997;7(2):107-11.

87. Niemi K, Häggman H, Sarjala T. Effects of exogenous diamines on the interaction between ectomycorrhizal fungi and adventitious root formation in Scots pine in vitro. Tree Physiol. 2002;22(6):373-81.

88. Kamauchi S, Nakatani H, Nakano C, Urade R. Gene expression in response to endoplasmic reticulum stress in Arabidopsis thaliana. FEBS J. 2005;272(13):3461-76.

89. Urade R. Cellular response to unfolded proteins in the endoplasmic reticulum of plants. FEBS J. 2007;274(5):1152-71.

90. Pottosin I, Shabala S. Polyamines control of cation transport across plant membranes: 
implications for ion homeostasis and abiotic stress signaling. Front Plant Sci. $2014 ; 5: 154$.

91. Mitsuya Y, Takahashi Y, Uehara Y, Berberich T, Miyazaki A, Takahashi H, et al. Identification of a novel Cys2/His2-type zinc-finger protein as a component of a spermine-signaling pathway in tobacco. J Plant Physiol. 2007;164(6):785-93.

92. Folk JE, Park MH, Chung SI, Schrode J, Lester EP, Cooper HL. Polyamines as physiological substrates for transglutaminases. J Biol Chem. 1980;255(8):3695-700. 